\title{
Um estudo comparativo das mudanças ideacionais na representação de Brás Cubas no par- linguístico português-espanhol
}

\author{
Giovanna Marcella Verdessi HOY ${ }^{1}$ \\ Adail Sebastião RODRIGUES JÚNIOR²
}

\footnotetext{
${ }^{1}$ Universidade Federal de Ouro Preto (UFOP), giovannaverdessihoy@yahoo.com.br, orcid. org/0000-0002-7802-3515, Papéis: conceptualização, curadoria de dados, investigação, análise formal, administração do projeto, recursos, metodologia, supervisão, escrita rascunho original, escrita - análise e edição.

${ }^{2}$ Universidade Federal de Ouro Preto (UFOP), adail.sebastiao@gmail.com, orcid.org/oooo০o03-1932-2862, Papéis: curadoria de dados, investigação, análise formal, metodologia, supervisão, escrita - rascunho original, escrita - análise e edição.
} 
RESUMO Neste estudo de caso, objetivase analisar as mudanças ideacionais nas representações de Brás Cubas, narrador e personagem principal de Memórias Póstumas de Brás Cubas (ASSIS, 1881) presentes na tradução de Alatorre (1951). Neste artigo, o conceito de mudanças ideacionais, cunhado por RodriguesJúnior e Garcia de Oliveira (2015), é entendido como a alteração em qualquer elemento da transitividade que provoca uma representação no texto alvo (TA) diferente daquela do Texto Fonte (TF) (HALLIDAY; MATTHIESSEN, 2014). O procedimento metodológico utilizado foi o uso das ferramentas do WordSmith Tools para descrição e análise dos elementos de transitividade. As análises confirmam a hipótese da pesquisa, a de que houve escolhas que provocaram mudanças ideacionais na representação ficcional de Brás Cubas. Verificou-se, igualmente, que as mudanças ideacionais nem sempre provocam a alteração na equivalência semântica.

ABSTRACT This study examines the ideational shifts related to the main character, Brás Cubas, in Machado de Assis' novel Memórias Póstumas de Brás Cubas (1881) in comparison with its translation into Spanish, Memórias Póstumas de Blas Cubas, by Antonio 
Alatorre (1951). The concept ideational shifts was coined by Rodrigues-Júnior e Garcia de Oliveira (2015) and means any change in the transitivity system (HALLIDAY; MATTHIESSEN, 2014) of the target text when compared to the same system adopted in the source text. The software WordSmith Tools was used to classify clauses according to their transitivity types. The results confirmed the hypothesis that the ideational shifts pointed to different forms of representing Brás Cubas, but such changes did not affect the semantic equivalence in the target text.

PALAVRAS-CHAVE Tradução Literária. Abordagens Textuais da Tradução. Mudanças Ideacionais. Memórias Póstumas de Brás Cubas.

KEYWORDS Literary Translation. Translation Textual Approach. Ideational Shifts. Memórias Póstumas de Brás Cubas. 
Que me conste, ainda ninguém relatou o seu próprio delírio; faço-o eu, e a ciência mo agradecerá. - Brás Cubas.

\section{Introdução}

Machado de Assis figura entre os mais renomados escritores brasileiros e sua obra tem sido traduzida em vários países, sobretudo naqueles de língua espanhola, como destacou há alguns anos Carlos Espinosa Domínguez (2010). Contudo, as traduções de Machado no mundo hispânico vêm aumentando gradativamente e podemos encontrá-las em países como a Argentina, a Espanha, o México e o Uruguai, por exemplo. Dentre essas, é de nosso interesse a tradução mexicana de Memórias Póstumas de Blas Cubas de Antonio Alatorre (1982[1951]), por ter uma distância de cinquenta anos do texto fonte e por ter sido feita por um conhecedor de Literatura e de Filologia.

A pesquisa está inserida nos Estudos Sistêmicos-funcionais em Tradução com foco na descrição do texto literário, mais especificamente na descrição das escolhas linguísticas que representam o mundo experiencial de Brás Cubas. Sendo assim, fizemos um estudo comparativo com o objetivo de analisar as mudanças ideacionais na representação do personagem principal e narrador do romance Memórias Póstumas de Brás Cubas (ASSIS, 1881) e de sua tradução para o espanhol mexicano (ALATORRE, 1982[1951]).

A escolha de um corpus da literatura brasileira se deve ao fato de que este, além de ser portador de significados experienciais, textuais e interpessoais, é um texto com um valor para a sociedade 
que o constitui em um artefato cultural, de acordo com Halliday e Matthiessen (2014). A esse respeito, Matthiessen (2017) se remete a Hasan (1985) para usar sua definição de literatura como arte verbal, revelando a importância deste produto cultural para a sociedade, pois há uma "atribuição de valor pelos seus membros" (MATTHIESSEN, 2017, p. 10) em torno desse objeto, como é o caso da obra machadiana.

Nesse sentido, Memórias Póstumas de Brás Cubas apresenta um valor atribuído pela comunidade leitora e até mesmo por boa parte do mundo das Letras, onde encontramos escolhas linguísticas presentes na tessitura de seu texto que caracterizam os eventos e personagens (MONTGOMERY, 1993), especialmente de seu personagem principal, Brás Cubas. Essas escolhas o destacam diante de tantos outros, devido a uma identidade própria e particular, caracterizado pela crítica literária como sendo o representante da aristocracia e burguesia brasileira do século XIX. Além disso, destacase também por ser um personagem denso e rico subjetivamente, sobretudo por ser construído como a testemunha dos fatos e aquele que julga as hipocrisias da sociedade de seu tempo, como afirma Bosi (2006). Em relação a esse personagem tão característico da obra machadiana, uma das dúvidas que surgem sobre essa representação ao ser traduzido ou retextualizado para outro idioma é se uma escolha linguística diferente da original provocará mudanças ideacionais na representação de suas experiências ficcionais; e, ocorrendo mudanças ideacionais nessa representação, de que forma isso ocorre e como se relaciona com a equivalência semântica.

Sabe-se que o trabalho do tradutor inclui muito mais do que a simples transcrição de uma palavra pela outra, uma vez que envolve, além de dois sistemas linguísticos, questões culturais, estilísticas, e, sobretudo a interpretação do texto por parte do tradutor. Por esse motivo, acreditamos que encontraremos determinadas escolhas linguísticas que provocam mudanças ideacionais e estas poderão 
afetar a representação ideacional do personagem principal de Memórias Póstumas de Brás Cubas, caracterizando-o de modo distinto do TF. Além disso, baseados nas conclusões de Rodrigues-Júnior e Garcia de Oliveira (2015), propomos que nem sempre a ocorrência de uma mudança ideacional resultará também em uma mudança na equivalência semântica ${ }^{3}$, embora isso também possa ocorrer.

O trabalho se justifica, em primeiro lugar, pela importância da obra selecionada, pois, se a qualidade da escrita machadiana é exemplar na literatura brasileira, Memórias Póstumas de Brás-Cubas (ASSIS, 1881) é, indiscutivelmente, uma de suas melhores produções literárias. A sua importância pode ser observada, por exemplo, quando o renomado crítico literário Alfredo Bossi (1978, p. 196) a nomeia como "divisor de águas”, “obra capital” (BOSSI, 1978, p. 197), "salto qualitativo" (BOSSI, 2006, p. 282). Em segundo lugar, poucas têm sido as pesquisas das abordagens textuais da tradução na análise das Memórias Póstumas de Brás-Cubas, distinguindo-se apenas a dissertação de Oliveira (2012) que pesquisou alguns dos capítulos da obra, diferentemente desta pesquisa que amplia a análise do personagem ao selecionar todos os capítulos onde ele está representado.

O artigo está dividido em seis seções com as seguintes temáticas, incluindo a introdução e a conclusão: a primeira é a contextualização da obra e do autor no texto fonte e texto alvo, de modo a entender as escolhas léxico-gramaticais do autor e do tradutor; na sequência, apresentamos o referencial teórico relacionado aos Estudos Sistêmicos Funcionais em Tradução; a terceira seção trata dos procedimentos metodológicos; e na quarta seção realizamos as análises e discutimos os dados.

${ }^{3}$ Embora Rodrigues-Júnior e Garcia de Oliveira (2015) tenham se baseado no conceito de equivalência semântica para discutir os resultados de sua pesquisa, esses autores não definiram esse tipo de equivalência. Para os propósitos deste estudo, entendemos equivalência semântica como escolhas no nível da oração que realizam significados equivalentes no texto-alvo quando em comparação com as mesmas escolhas no texto-fonte. 


\section{Contextualização da obra e do autor no texto fonte e texto alvo}

As Memórias Póstumas de Brás Cubas foram publicadas primeiramente na forma de folhetins em um periódico do Rio de Janeiro chamado Revista Brasileira durante o ano de 1880. Essa prática foi muito frequente em jornais da época e tinham a finalidade de despertar maior interesse, aumentando seu públicoleitor, sobretudo, do público feminino, segundo aponta pesquisa de Farias (2013).É por esse motivo que essa obra foi publicada no formato de livro somente um ano depois, em 1881, pois seu primeiro meio de publicação havia sido o folhetim, como dito anteriormente.

Em linhas gerais, a história trata de um defunto autor que conta suas memórias quando vivo, durante o início do século XIX, apresentando a sociedade daquele período histórico. Nesta obra ficcional, é sob o ponto de vista narrativo de um defunto autor que as marcas da aristocracia escravista e o surgimento de uma incipiente burguesia são apresentadas, isto é, por meio de um narrador que representa esta elite que a sociedade é descortinada, uma vez que ele é filho de um rico proprietário de terras que enriqueceu durante o auge do período colonial (SCHWARZ, 1990; OLIVEIRA, 2012).É sob o olhar deste personagem narrador que essa sociedade passa pelo crivo de sua mordaz crítica, ao desvelar aspectos sociais por meio da descrição de si mesmo e de outros personagens mediante uma narrativa do além, desprovida de qualquer tipo de controle.

Em relação a esse aspecto memorialístico, Bosi (2006) ressalta o papel de Brás Cubas, que se desdobra de duas formas complementares: um narrador que, mediante sua fala, atesta ter participado dos fatos e outro que, na figura do defunto autor, julga os fatos sem o véu das convenções e hipocrisias sociais. A utilização do recurso narrativo do defunto autor desvela um aspecto mais profundo do valor testemunhal de Brás Cubas, uma vez que “ele 
surpreende-se a si próprio como ator e espectador no processo das relações de força entre os sujeitos" (BOSI, 2006, p. 182).

Embora parte da crítica literária situe esta obra no realismo, devido ao detalhamento da sociedade e à presença de uma crítica sarcástica do narrador em relação a essa sociedade, o crítico literário Carlos Fuentes (2000) destaca que Machado de Assis não é herdeiro da tradição antiquada do realismo e do romantismo, e sim da tradição de Don Quixote de la Mancha, de Cervantes. Para ele, Machado é um milagre do século XIX, aquele que já havia ocorrido na Espanha de Cervantes e que agora surge no Brasil, país herdeiro da língua portuguesa.

Sendo assim, é na narrativa memorialística que Brás Cubas revela a sociedade brasileira do século XIX, o Brasil Império, e mais especialmente, a elite daquele tempo (SCHWARZ, 1990). Sob o olhar do narrador, identificamos, por um lado, a frivolidade, a ganância, o luxo, a opressão da aristocracia brasileira e da burguesia que começava a despontar no país do século XIX, e por outro, os explorados por essas classes, representados pela escravidão e pelas camadas menos favorecidas que surgem na composição de personagens menos centrais, como os escravos de seu pai, a empregada Dona Plácida, por exemplo.

A tradução de Memorias Póstumas de Blás Cubas para o espanhol mexicano foi realizada por Antônio Alatorre, em 1951, publicada pela editora Fundo de Cultura Econômica e reimpressa pela Casa de las Américas em 1982. Apesar de a bibliografia consultada não deixar claro se Alatorre era conhecedor da obra machadiana, é muito provável que sim, devido à sua formação e grande erudição. Ele foi filólogo e estudioso da literatura espanhola, crítico literário, escritor, linguista, tradutor e professor da Universidade Nacional Autônoma do México (UNAM) e do El Colégio de México. Conhecedor do inglês, italiano e português, além de outras línguas, Alatorre destacou-se pela tradução de obras como Language: an Introduction to the Study 
of Speech, de Edward Sapir, em 1954; La disputa del Nuovo Mondo, de Antonello Gerbi, em 1960 (PAREDES, 2010); e Memórias Póstumas de Brás Cubas, de Machado de Assis, em 1951.

O reconhecimento do valor de Alatorre em áreas que vão da literatura à tradução veio coroada por diversos prêmios. Um deles foi a Medalha José María Vigil, concedida, em 1956, por seu trabalho como pesquisador em literatura e diversos assuntos afins en El Colegio de México. Também recebeu o Premio José Gaos, outorgado pelo Instituto de Intérpretes e Tradutores em 1991, e, ainda, a conquista do Premio Nacional de Ciências e Artes no campo da Linguística e Literatura, em 1998 (PAREDES, 2010; LARA, 2011).

\section{Referencial teórico: Estudos da Tradução e Estudos Sistêmicos Funcionais em Tradução}

Munday (2001) distingue autores que adotam uma abordagem mais sistemática e orientada linguisticamente em relação ao estudo da tradução durante a década de 1950 e 1960, tais como Jean-Paul Vinay and Jean Darbelnet (1958), Georges Mounin (1963) e Eugene Nida (1964). Destes, Nida (2000, p. 127) apresenta a ideia de que "duas línguas não são idênticas e, por isso, [...] é evidente que não pode haver correspondência absoluta entre línguas", ainda mais ao se levar em conta os contextos diferentes e a capacidade interpretativa do tradutor que não é apenas um reprodutor de palavras, mas um leitor, primeiramente. A hipótese defendida por Nida (2000) mostra que a correspondência absoluta é uma falácia, não havendo essa possibilidade entre duas línguas diferentes, o que reforça a ideia desta pesquisa de que mudanças ideacionais fazem parte de todo produto tradutório e que serão identificadas até mesmo em uma tradução feita por alguém que prima pela palavra.

${ }^{4}$ Todas as traduções são de nossa autoria e responsabilidade. 
Outro autor que se destaca pela contribuição às abordagens textuais da tradução é Catford (1965), pois não é possível deixar de reconhecer o valor da contribuição ao trabalhar com os conceitos de correspondência formal e equivalência textual, a partir dos quais introduz o conceito de mudança (shifts), com base na Linguística Sistêmico Funcional (LSF). Essas mudanças (shifts) ocorreriam, segundo o autor, quando não fosse possível encontrar a correspondência formal, revelandoum aspecto do sistemalinguístico que abre espaço para vários tipos de mudanças, assim como as ideacionais que são abordadas neste artigo e que foram estudadas por outros autores recentemente (RODRIGUES-JÚNIOR; GARCIA DE OLIVEIRA, 2015).

Seu pioneirismo deve-se, sobretudo, ao conciliar os Estudos da Tradução e a LSF. Até mesmo Matthiessen (2001, p. 43) reconhece a importância do trabalho de Catford dizendo que "a tarefa teórica central [dos novos pesquisadores] é expandir a sua proposta à luz dos novos desenvolvimentos teóricos e descobertas descritivas". Um trabalho que coaduna com os pressupostos da LSF, que defende um estudo descritivo da linguagem, como o que se faz neste trabalho, o que exclui qualquer tipo de prescrição por não fazer parte do uso real da língua.

No século XX, Matthiessen (2001) representa novos desenvolvimentos teóricos dessa área. Ele promove uma discussão da equivalência e da mudança sob uma nova perspectiva, discutindo esses conceitos no nível das metafunções. Segundo o autor, a tradução está mais próxima do nível semântico do que do léxicogramático, cuja localização aproximada é o contexto de cultura do texto de origem (MATTHIESSEN, 2001). E é justamente com base nestes dois últimos autores, Catford (1965) e Matthiessen (2001), que Rodrigues-Júnior e Garcia de Oliveira (2015) propuseram o conceito de mudanças ideacionais, conceito relevante para esta 
pesquisa. Contudo, nas palavras dos autores, é uma ampliação dos trabalhos anteriores, pois não se prende somente à 'mudança-classe gramatical' - como em Catford, mas volta-se para as "mudanças nos níveis da ideação", que focaliza os elementos da metafunção ideacional, isto é, os "processos, participantes, circunstâncias e expansões" (RODRIGUES-JÚNIOR; GARCIA DE OLIVEIRA, 2015, p. 399). As mudanças ideacionais ocorreriam, segundo os autores, quando um desses elementos fosse alterado, como se vê no exemplo a seguir:

Exemplo $1^{5}$ :

Virei (MAT) e revirei (MAT) o papel.
Miré (COM) y remiré (COM) el papel.

No exemplo 1, a representação ideacional de Brás Cubas no TF é a de um Ator (virei e revirei) que executa duas ações sobre uma Meta (o papel), um bilhete que havia recebido. É alguém que age com certo nervosismo ao repetir uma mesma ação sobre a meta, o pedaço de papel que era um bilhete de sua amada para que ajudasse uma velha empregada. No TA a representação ideacional de Brás Cubas é sutilmente alterada provocando uma mudança ideacional. Ele é representado não como um Ator que age sobre o papel e que mostra seu nervosismo ao repetir essa ação, mas como um comportante que apenas olha (mirê) o bilhete com insistência, porém, repetindo o comportamento (remiré), como quem indaga a procedência e o porquê desse pedido, demonstrando assim o incômodo com o conteúdo do bilhete.

${ }_{5}^{5}$ Todos os exemplos foram retirados do corpus desta pesquisa. 
A análise mostra o potencial da LSF na descrição e análise do texto traduzido, especialmente, do texto literário. Nota-se, portanto, que as pesquisas nas abordagens textuais da tradução têm sido úteis para análise de diversos aspectos dos textos, dentre os quais os significados ideacionais, textuais e interpessoais.

Na próxima seção é detalhado o sistema de transitividade e o complexo oracional da Metafunção Ideacional.

\subsection{Metafunção Ideacional: o sistema de transitividade e o complexo oracional}

A Metafunção Ideacional organiza discursivamente o fluxo de experiências sociais, culturais e da consciência dos seres humanos por meio do sistema de transitividade. Sobre o sistema de transitividade, Halliday (1982[1978]) explica que:

a linguagem interpreta nossa experiência, reduzindo os fenômenos infinitamente variados do mundo que nos cerca, e também de nosso mundo interno, dos processos de nossa consciência, a um número controlável de classes de fenômenos: tipos de processos, acontecimentos e ações, classes de objetos, de gente e de instituições (HALLIDAY, 1982 [1978], p.33).

Depreende-se disso que, para a LSF, o termo representação, diferentemente de outras áreas do conhecimento, refere-se ao uso da linguagem para organizar as experiências humanas por meio do sistema de transitividade da metafunção ideacional. Esse sistema é responsável pela codificação gramatical das experiências humanas e produz uma figura (figure) constituída por processos (verbos), participantes (grupos nominais) e, ocasionalmente, circunstâncias (sintagmas preposicionados e grupos adverbiais). 
Os processos são os eventos da experiência que, junto aos participantes desses eventos, constituem o centro experiencial dessa figura, enquanto as circunstâncias são consideradas elementos menos centrais. Elas contribuem com informações adicionais, que podem iluminar certos detalhes, tais como, localização, tempo, frequência, modo do evento, entre outras (HALLIDAY; MATTHIESSEN, 2014).

Para exemplificar, a figura experiencial mostra os processos, participantes e circunstâncias no exemplo 2, a seguir:

Exemplo 2: quando eu nasci

(a) (b) (c)

No excerto 1, identifica-se um processo material (c) que indica as experiências de mundo ficcional de Brás Cubas como participante ator (b). A figura do excerto 1 mostra a representação das experiências de mundo ficcional de Brás Cubas. Para complementar, essa experiência está circunscrita a determinado momento indicado pela circunstância de tempo (a), que dá uma característica específica a essa experiência. Assim, essas e outras figuras são modelagens das experiências humanas (ou goings on em termos hallidianos) reais ou ficcionais realizadas pela linguagem mediante seis tipos de processos. Segundo Halliday e Mathiessen (2014) estes são os materiais, relacionais, mentais, verbais, existenciais e comportamentais, e para cada um deles haverá pelo menos um participante obrigatório, como se vê no quadro 1, a seguir: 
Quadro 1: Tipos de Processos e seus Participantes

\begin{tabular}{|c|c|c|c|}
\hline $\begin{array}{c}\text { Tipos de } \\
\text { Processos }\end{array}$ & $\begin{array}{c}\text { Participantes } \\
\text { obrigatórios }\end{array}$ & $\begin{array}{l}\text { Realizados } \\
\text { por verbos }\end{array}$ & Exemplo \\
\hline Materiais & $\begin{array}{l}\text { Ator } \\
\text { Meta } \\
\text { Beneficiário } \\
\text { Escopo } \\
\text { Atributo }\end{array}$ & $\begin{array}{l}\text { Fazer } \\
\text { Ir }\end{array}$ & Fui aos alforjes \\
\hline Relacionais & $\begin{array}{l}\text { Portador } \\
\text { Atributo } \\
\text { Identificador } \\
\text { Identificado }\end{array}$ & $\begin{array}{l}\text { Ser } \\
\text { Ter }\end{array}$ & $\begin{array}{l}{[\ldots] \text { eu não sou }} \\
\text { propriamente } \\
\text { um autor } \\
\text { defunto }\end{array}$ \\
\hline Mentais & $\begin{array}{l}\text { Experienciador } \\
\text { Fenômeno }\end{array}$ & $\begin{array}{l}\text { Saber } \\
\text { Perceber }\end{array}$ & $\begin{array}{l}\text { Era o que } \\
\text { eu pensava } \\
\text { comigo }[. . .]\end{array}$ \\
\hline Verbais & $\begin{array}{l}\text { Dizente } \\
\text { Receptor } \\
\text { Verbiagem } \\
\text { Alvo }\end{array}$ & $\begin{array}{l}\text { Falar } \\
\text { Dizer }\end{array}$ & $\begin{array}{l}\text { confesso } \\
\text { que era um } \\
\text { problema } \\
\text { insolúvel }[. . .]\end{array}$ \\
\hline Existenciais & Existente & $\begin{array}{l}\text { Haver } \\
\text { Existir }\end{array}$ & $\begin{array}{l}\text { há coisas } \\
\text { que se não } \\
\text { podem reaver } \\
\text { integralmente } \\
{[\ldots]}\end{array}$ \\
\hline Comportamentais & $\begin{array}{l}\text { Comportante } \\
\text { Comportamento }\end{array}$ & $\begin{array}{l}\text { Dormir } \\
\text { Respirar }\end{array}$ & $\begin{array}{l}\text { Começo a } \\
\text { ficar patético } \\
\text { e prefiro } \\
\text { dormir }{ }^{6} .\end{array}$ \\
\hline
\end{tabular}

Fonte: Adaptado de Halliday e Matthiessen (2004, 2014)

\footnotetext{
${ }^{6}$ Segundo Halliday e Matthiessen (2014, p.302), os processos comportamentais não apresentam características que os distingam claramente, apresentando aspectos de atividades psicológicas e fisiológicas. Por isso, eles podem estar próximos aos processos mentais (ouvir/listen); próximos aos materiais (sentar/sit down); e próximos aos verbais (falar/talk). Fuzer e Cabral (2014) apresentam uma lista de processos comportamentais no português brasileiro com base em Hallidaye Matthiessen (2004), tais como: chorar, respirar, dormir, levantar, olhar, gargalhar etc. (p. 77). Em relação aos processos comportamentais em espanhol, Ghio e Fernández (2008) apresentam: oler (cheirar), escuchar (escutar), mirar (olhar), sonreir (sorrir), roncar (roncar), entre outros.
} 
No tocante ao complexo oracional, Halliday e Matthiessen (2014, p. 428) explicam que, quando temos mais de uma oração, elas estão "ligadas umas às outras por meio de algum tipo de relação lógicosemântica para formar complexos oracionais". Ainda segundo os autores, essas orações em conjunto produzem significados experienciais, textuais einterpessoais e representam figuras (figures), que estão relacionadas entre si (HALLIDAY; MATTHIESSEN, 2014); sendo, portanto, os significados experienciais que estão em foco neste trabalho. É importante lembrar que os complexos oracionais podem ser identificados em Expansões de vários tipos de Processos e nas Projeções de processos mentais e verbais.

\section{Procedimentos metodológicos: 0 WordSmith Tolls 6.0 como instrumento de organização de dados}

Atualmente, o desenvolvimento da tecnologia tem permitido, não somente o trabalho com um número cada vez maior de corpora, como também tem facilitado o exame mais aprofundado em função do uso de um número cada vez maior de ferramentas computacionais (BERBER SARDINHA, 2004). Essa mudança concorreu para o desenvolvimento da Linguística de Corpus (LC), que vem sendo utilizada não só como referencial teórico, mas, sobretudo, metodológico, ao buscar entender o corpus através da "observação empírica dos fatos linguísticos" (NOVODVORSKI; FINATTO, 2014, p. 10). Segundo Berber Sardinha (2004, p. 35-38), isso ocorre porque a LC pode ser entendida tanto como "teoria" quanto "metodologia" e, inclusive, como "abordagem baseada em corpus", dependendo do enfoque e do uso que se dê ela.

Com base nas abordagens textuais da tradução, neste estudo de caso adotamos a LC como metodologia, isto é, como um instrumental capaz de auxiliar na descrição dos corpora, de modo a 
identificar características linguísticas, padrões de uso e recorrências. Com esse propósito, utiliza-se o programa computacional WordSmith Tools, versão 6.0, por facilitar a localização das palavras e visualização de seu comportamento em contexto (BERBER SARDINHA, 1999).

Como primeira etapa da organização dos dados foi feito o levantamento dos itens lexicais mais frequentes com a ferramenta lista de palavras do WordSmith Tools no TF e TA. A partir dessas listas, eliminaram-se aquelas palavras que não seriam utilizadas, deixandose apenas os Processos (verbos), a fim de identificar as experiências de mundo ficcionais de Brás Cubas presentes nas linhas de concordância dos textos fonte e texto alvo. Em seguida, os Processos vinculados a Brás Cubas foram organizados pelo Concord em linhas de concordância, a fim de classificar os tipos de processos e realizar o etiquetado destes, com parênteses, de acordo com a legenda do quadro 2:

Quadro 2: Legendas para os Processos

\begin{tabular}{|l|c|}
\hline \multicolumn{1}{|c|}{ Tipos de Processos } & Etiquetas \\
\hline MATERIAL & $(\mathrm{MAT})$ \\
\hline RELACIONAL & $(\mathrm{REL})$ \\
\hline MENTAL & $(\mathrm{MEN})$ \\
\hline EXISTENCIAL & $(\mathrm{EXI})$ \\
\hline COMPORTAMENTAL & $(\mathrm{COM})$ \\
\hline VERBAL & $(\mathrm{VER})$ \\
\hline
\end{tabular}

Após a etiquetagem dos Processos, a contagem foi realizada no TF e no TA por meio da ferramenta Concord, como se pode ver nos excertos extraídos do corpus analisado, na figura 1: 
Figura 1: Processos mentais (MEN) nas linhas de concordância

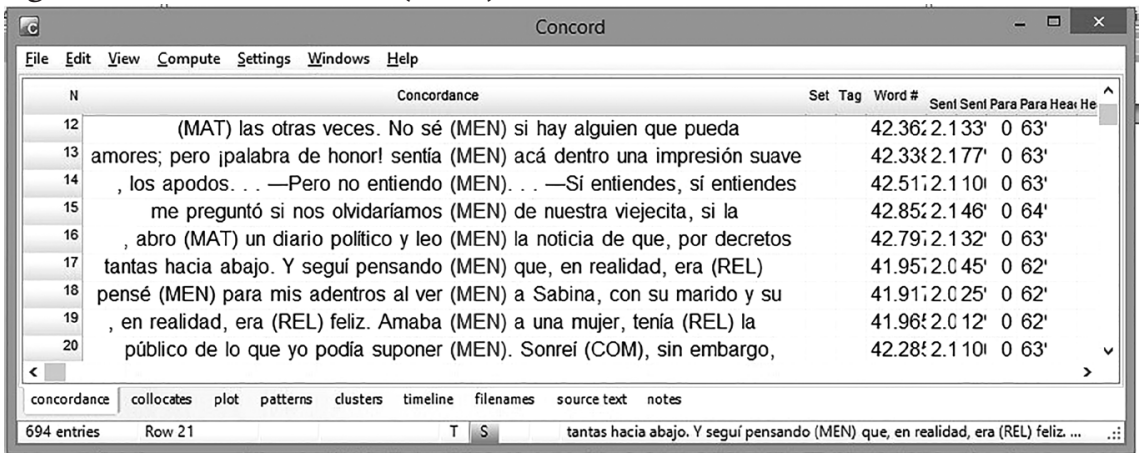

A última etapa foi o alinhamento das linhas de concordância do TF com o TA, por meio do Aligner, a fim de facilitar a comparação entre os textos com o objetivo de identificar as mudanças ideacionais. Na seção de análise, os dados foram organizados de modo a facilitar a leitura e a mostrar o cotexto das escolhas léxico-gramaticais vinculadas a Brás Cubas da seguinte maneira: os Processos foram negritados; as Circunstâncias foram colocadas em itálico acrescentando-se o parêntese com (CIR); a omissão foi identificada entre parênteses e em caixa alta (OMISSÃO), conforme exemplo 3:

\section{Exemplo 3:}

A meio caminho, chamaram-lhe "linda Marcela", lembrou-me (MEN) que ouvira (COM) tal nome a meu tio João, e fiquei (REL), confesso (VER) que fiquei (REL) tonto.

A medio camino la llamaron "linda Marcela"; recordé (MEN) haber oído (COM) ese nombre a mi tío Juan, y, (OMISSÃO) lo confieso (VER), quedé (REL) todo (CIR) aturdido.

Para a análise qualitativa, por questões de espaço, foram selecionados oito excertos, representativos do corpus investigado, sendo dois exemplos para cada tipo de mudança (Tabela 2), isto é, dois exemplos para: Omissão de Processo; Acréscimo de Processo; Omissão de Circunstância; e Acréscimo de Circunstância. 
Na seção seguinte, seguem as análises dos dados.

\section{Discussão e Análises dos dados: mudanças ideacionais em Brás Cubas}

Como explicado na metodologia, os Processos da lista de palavras foram etiquetados no Concord, sendo contabilizados e organizados em uma tabela (Tabela 1) que mostra as escolhas léxico-gramaticais utilizadas por Machado e Alatorre quando vinculadas ao narrador e personagem principal, Brás Cubas.

Tabela 1: Representação Ideacional de Brás Cubas no TF e TA

\begin{tabular}{lcc}
\hline \multicolumn{1}{l}{ Tipos de Processos } & Pt & Es \\
\hline Materiais & 851 & 832 \\
Mentais & 689 & 694 \\
Verbais & 506 & 514 \\
Comportamentais & 314 & 308 \\
Relacionais & 238 & 236 \\
\hline Total & 2598 & 2584 \\
\hline
\end{tabular}

Na Tabela 1, estão organizados os processos vinculados a Brás Cubas, notando-se que a representação ideacional desse personagem é diversificada, haja vista que conta com todos os tipos de processos, com maior uso para os materiais, mentais e verbais. Desse modo, Brás Cubas é um ator de sua vida, um ser consciente, que pensa sobre seu entorno e um Dizente que quer falar sobre essa vida. Como Ator, é alguém que atua em seu entorno, realizando diversas atividades, como examinar dinheiro (excerto 1), puxar a amada para si (excerto 4). Já como Experienciador e Dizente, é representado como alguém que pensa e fala bastante pela voz narrativa, característica marcante de um texto em prosa de cunho memorialístico. 
Em termos numéricos, à primeira vista, os dados da tabela 1 sugerem elevados índices de equivalências ideacionais entre $o$ TF (2.598) e o TA (2584), o que, no entanto, um olhar mais atento irá revelar mudanças ideacionais, como proposto na hipótese deste trabalho. Em relação à equivalência ideacional que o TA tenta reproduzir do TF, ela aproxima-se àquela que Nida (2000) denominou de formal, isto é, aquela que "destina-se a revelar, tanto quanto possível, a forma e ao conteúdo da mensagem original" (p. 134). No entanto, o próprio Nida (2000) esclarece que este tipo de equivalência não pode ser mantida o tempo todo, devido ao fato de não existirem duas línguas iguais no mundo. Quando este tipo de equivalência ocorre em um texto, o tradutor lança mão de notas explicativas para dar conta do aspecto linguístico do TF, e, de fato, na tradução de Alatorre temos a presença de 72 notas explicativas no TA (NIDA, 2000) que revelam a presença também de escolhas linguísticas que provocam mudanças ideacionais na representação de Brás Cubas.

No tocante às mudanças, verificamos algumas delas que foram organizadas na tabela 2, abaixo.

Tabela 2: Mudanças Ideacionais

\begin{tabular}{lcc}
\hline Mudanças Ideacionais & Es & $\%$ \\
Omissão de Processo & 13 & $0.5 \%$ \\
Acréscimo de Processo & 8 & $0.3 \%$ \\
Omissão de Circunstância & 3 & $0.1 \%$ \\
Acréscimo de Circunstância & 11 & $0.4 \%$ \\
\hline Total & 35 & $13 \%$ \\
\hline
\end{tabular}

A tabela 2 revela pequenas diferenças entre alguns processos e a presença de omissões e acréscimos que são indicativos de mudanças ideacionais. Por certo, as linhas de concordância com os textos lado a lado disponibilizadas pelo Aligner confirmaram essa hipótese, como se verá nos excertos analisados. 
A pesquisa de Oliveira (2012) identificou a presença de um grande número de processos relacionais no TA que apontam várias ocorrências de mudanças ideacionais na representação de Brás Cubas. Nesta pesquisa, no entanto, o resultado dos dados revela algo diferente da conclusão de Oliveira (2012), uma vez que o perfil ideacional de Brás Cubas no TA é semelhante ao TF. Porém, nota-se uma pequena diferença de $1 \%$ nos processos materiais, e outras de menos de $1 \%$ em outros processos (mentais, verbais e comportamentais). Embora estas mudanças sejam pequenas, as escolhas "não existem isoladamente, mas na relação com outras possíveis escolhas que o falante ou escritor descartou ou não utilizou" (MUNDAY, 2012, p. 13).

Da tabela 2, também foram observados casos de omissões de Processos e Circunstâncias (0.5\% e 01\%) e acréscimos de Processos e Circunstâncias (0.3\% e 0.4\%) que estão relacionados a mudanças ideacionais no TA como se demonstrará na análise dos excertos mais adiante.

Os dados quantitativos permitem a observação de pistas ou indícios de escolhas tradutórias que sugerem a presença de mudanças ideacionais na representação de Brás Cubas e, por isso, cabe uma análise qualitativa dos dados de modo a identificar os tipos de mudanças.

\subsection{Análise qualitativa dos dados}

Contexto do Excerto 1:

O contexto do excerto (1) refere-se ao momento em que Brás Cubas, após ter encontrado um embrulho na praia contendo muito dinheiro, o guarda em seu escritório para mais tarde, após o jantar, voltar a verificar o seu conteúdo. 
Excerto 1: Acréscimo de Circunstância

Sobre o jantar fui (MAT) outra vez ao gabinete, examinei (MAT) o dinheiro, e rime (COM) dos meus cuidados maternais a respeito de cinco contos, - eu, que era (REL) abastado.

Después de la cena fui (MAT) otra vez a mi cuarto, examiné (MAT) el dinero y me reí (COM) de mis cuidados maternales para con aquellos cinco contos... yo, que era (REL) bastante rico.

No excerto (1), a representação ideacional de Brás Cubas na oração principal é de um ator que se desloca por meio do processo material (fui). Os processos presentes no complexo oracional complementam a representação de Brás Cubas caracterizando-o como Ator (examinei), Comportante (ri) e Portador (era). A representação de Brás como Ator dá conta do ato de examinar atentamente o dinheiro achado na rua, cujo desejo não inclui a sua devolução ao verdadeiro dono, rindo da situação ( $r i$ ), justamente por ele ser uma pessoa abastada (era). Esse conjunto de figuras experienciais representa um narrador complexo que age e se comporta de modo mesquinho em relaçãoao dinheiro que pretende se apropriar, mesmo não sendo o seu dono, contrastando radicalmente com uma de suas principais características, a de ser (era) abastado. Com essa representação, o ponto de vista narrativo evidencia a avareza do narrador, um homem abastado que, no entanto, não teria escrúpulos em ficar com um dinheiro achado na rua.

Nesse excerto (1), observam-se os mesmos processos no TA para representar o narrador, porém, o acréscimo de uma circunstância de intensidade (bastante) produz uma mudança ideacional na representação das experiências ficcionais de Brás Cubas ao intensificar uma das principais qualidades do personagem. Desse modo, ele é um portador de um atributo (rico), mas este atributo é intensificado (bastante), marca que realiza linguisticamente um Brás Cubas pertencente ao grupo de homens mais ricos daquela sociedade e que destaca ainda mais a sua mesquinhez. 
Contexto do Excerto 2:

O excerto (2) mostra um episódio da história mundial que divide a sua família: em aqueles que apoiam e aqueles que são contra a primeira queda de Napoleão Bonaparte (1814), quando Brás Cubas tinha apenas nove anos de idade. É nesse contexto que o pai de Brás Cubas oferece um jantar para comemorar o fato e muitos são os que, sendo a favor, fazem seus discursos inflamados que não interessam ao pequeno Brás, cujo único interesse era apenas brincar com um espadim que acabara de ganhar.

Excerto 2: Acréscimo de Circunstância

E notem que eu ouvi (COM) muito discurso, quando era (REL) vivo, li (MEN) muita página rumorosa (rumor) de grandes ideias e maiores palavras...

Y notad que oí (COM) no pocos discursos durante mi vida (CIR), que leí (MEN) no pocas páginas atestadas (testigo) de grandes ideas y de palabras más grandes aún...

No excerto (2), no qual Brás Cubas é representado no complexo oracional como Comportante (ouvi), Portador (era) e Experienciador (li). Constitui-se com essas figuras experienciais de Brás Cubas, uma representação que denota a sua participação em diversos eventos onde teve oportunidade de ser um ouvinte e leitor de diversos tipos de discursos, cuja qualidade (vivo) o situa entre os homens vivos, e o tempo pretérito do processo (era) revela a época em que ele participava desses eventos. Essas representações constroem a representação ideacional de homem letrado que participa de eventos discursivos e por meio de comportamentos e de experiências ficcionais (ouvi, li) típicas da elite, do grupo social a que pertencia quando vivo.

É interessante notar que o texto traduzido constrói a mesma representação de Brás-Cubas como Comportante (oî) e 
Experienciador (lê), mantendo a mesma representação social constatada no texto-fonte. Contudo, ocorre uma quebra no complexo oracional; e o Processo relacional (era) é omitido. No lugar do processo é utilizada uma Circunstância de tempo (durante mi vida), produzindo, assim, a mesma ideia de tempo passada da conjugação temporal do processo no passado (oí e leî) do TF. Dessa forma, a omissão exclui uma das representações de Brás-Cubas provocando uma mudança ideacional na figura que representa uma de suas qualidades, a de ter sido um ser vivente à época de suas experiências comportamentais e experienciais que formavam sua identidade social, embora boa parte da equivalência semântica tenha sido mantida. ${ }^{7}$

\section{Contexto do Excerto 3:}

Este excerto está situado em um momento da vida de Brás em que teve um acidente com um jumento. O narrador personagem logo passa a bater com a vara o pobre animal que sacudiu Brás Cubas para fora da cela, ficando este preso ao estribo. O defunto autor narra este fato rememorando o acontecido.

\section{Excerto 3: Omissão de Processo}

E era verdade; se o jumento corre por ali fora, contundia-me deveras, e não sei (MEN) se a morte não estaria no fim do desastre; cabeça partida, uma congestão, qualquer transtorno cá dentro, lá se me ia a ciência em flor.

Y era verdad; si el macho ha llegado a correr, me habría dado una descalabrada espantosa, y (OMISSÃO) quizá la muerte hubiera sido el remate de semejante desastre; cabeza rota, una congestión, cualquier, trastorno acá dentro, y adiós ciencia en flor.

\footnotetext{
7 É interessante notar que aqui o tradutor utiliza um recurso da língua que Halliday e Matthiessen (2014) denominam de metáfora gramatical, na qual ocorre uma nominalização do Processo, e este passa a ser o participante da oração. Esse é um recurso muito utilizado no discurso científico com o intuito de criar novos significados à língua.
} 
No TF do excerto (3), Brás Cubas, na condição de narrador/ personagem, é representado como experienciador de uma incerteza mediante o processo mental (sei) e da polaridade negativa (não). Este recurso dá a conhecer as experiências internas do narrador em primeira pessoa que, ao rememorar o passado, reconstrói um dos fatos de sua própria vida na oração projetada (se a morte não estaria no fim do desastre...). Essas escolhas léxico-gramaticais foram influenciadas pelo contexto autobiográfico desta obra ficcional, pois permitem que o narrador possa "transformar-se em um sujeito capaz de refletir sobre o tempo vivido" (LEAL, 2013, p. 30).

As escolhas léxico-gramaticais no TA omitem o processo mental (sei) substituindo-o por um advérbio de dúvida (quizá), mantendo uma equivalência semântica de incerteza, embora produza uma mudança ideacional na representação de Brás Cubas como experienciador, em virtude da omissão de sei.

\section{Contexto do Excerto 4:}

No excerto (4), o narrador conta um episódio da trama, ocorrido quando voltavam de um passeio, em que fica no ar certo desconforto de Virgília; instantes antes desse mal-estar os dois trocaram carícias apaixonadas. Vendo-a nesse estado, ele se preocupa com a amada e a conforta com seus carinhos.

\section{Excerto 4: Omissão de Processo}

Travei-lhe (MAT) das mãos, puxei-a (MAT) levemente a mim, e beijei-a (MAT) na testa, com uma delicadeza de zéfiro e uma gravidade de Abraão.

La tomé (MAT) de las manos, la atraje (MAT) levemente hacía mí, (Omissão) con una delicadeza de céfiro y una gravedad de Abraham...

No excerto (4), a representação ideacional de Brás Cubas no TF é a de um Ator (travei; puxei; beijei) que executa três ações sobre uma Meta (lhe; a; a), a mulher amada. Na representação ideacional 
do narrador, a ação de (puxar) a amada até seu corpo é textualizada pela circunstância de modo (levemente), que junto com o processo material transformativo de contato (beijei) constituem a representação de um Ator cuidadoso, delicado e afetuoso com seu par romântico.

A representação no TA é em parte mantida, pois Brás Cubas é um Ator de duas ações (tomé; atraje) que atingem a mulher amada (Meta), sendo a última ação situada em um contexto (levemente) de delicadeza e cuidado em relação à mulher. Entretanto, há uma mudança na representação ideacional que constitui Brás Cubas ao seromitidooprocesso materialbeijei, poisse, deumlado, sãomantidas as características de delicadeza e cuidado, de outro, modifica-se o afeto de alguém apaixonado que é capaz de dar um beijo na testa de sua amada. Com isso, verificando-se uma alteração sutil de aspectos experienciais do personagem com a omissão do processo beijei.

\section{Contexto do Excerto 5:}

No excerto (5), Brás Cubas jovem encontra-se em um navio em direção à Europa com o capitão dessa embarcação. Nessa parte da trama, o capitão mostra seu lado poeta para Brás Cubas ao recitar seus versos, explicando-lhe que se trata de sua melhor obra e consegue a confirmação por parte desse Brás Cubas jovem.

\section{Excerto 5: Acréscimo de Processo}

No fim, confessou-me que era a sua obra mais acabada; eu disse-lhe (VER) que $\operatorname{sim} ;(.$.

Al fin me confesó que aquella era su obra más acabada; yo le dije (VER) que así lo creía (MEN); (...)

No excerto (5) a voz narrativa no TF constrói uma representação ideacional de Brás Cubas no âmbito da fala (disse) dirigida a um conhecido. A Projeção (que sim) indica o conteúdo da fala de Brás 
Cubas, que concorda com o amigo, o Receptor a quem a sua fala é dirigida (lhe). No TA há uma mudança ideacional na presença da projeção de locução (que así lo creía), produzindo-se uma nova figura (figure) das experiências do narrador/personagem. Visto que toda projeção deve ser analisada como uma oração autônoma (HALLIDAY; MATTHIESSEN, 2014), observa-se que nela Brás Cubas é representado como um Experienciador (creía) de algo que não ocorre no texto fonte. Esta oração projetada situa Brás Cubas no campo semântico da consciência, revelando um pensamento que não é categórico, mas uma possibilidade (creía), diferentemente do texto fonte, onde há uma afirmação e concordância com o seu interlocutor (que sim).

Contexto do Excerto (6):

O excerto (6) situa Brás Cubas no momento em que ele e Virgília decidem alugar uma casa para seus encontros e ele passa a refletir sobre necessidade de posse e egoísmo que isso significa.

Excerto 6: Acréscimo de Processo

Tais eram as reflexões que eu vinha fazendo (MAT), por aquele Valongo fora, logo depois de ver (COM) e ajustar (MAT) a casa.

Tales eran las reflexiones que venía haciendo (MAT) al caminar (MAT) por Valongo, después de ver (COM) y contratar (MAT) la casa.

A representação de Brás Cubas no excerto (6) é a de um Ator (fazendo) de reflexões, de um Experienciador (ver) que observa a casa cujo interesse é de alugar para seus encontros com Virgília e a de um Ator (ajusta) que ajusta oaluguelda casaapós realizaro contrato. Essas experiências ficcionais estão circunscritas a um local específico (por aquele Valongo afora) que ilumina um detalhe importante dessa experiência, o local onde seus planos seriam levados à concretude, ou seja, onde iriam manter seus encontros após acertar a casa. 
No TA, a representação ideacional de Brás Cubas é acrescida de mais uma experiência ficcional, a de uma ação (caminar) em um determinado lugar (por Valongo) que criam uma representação mais dinâmica, mostrando uma ação no campo semântico da materialidade desse personagem.

\section{Contexto do Excerto 7:}

No excerto (7) temos a representação de Brás Cubas ainda menino, já possuidor de uma maldade inerente ao seu ser. Nem mesmo as tentativas de sua mãe de colocá-lo no bom caminho, ao ensinar-lhe algumas orações, por exemplo, serviam para que ele se tornasse um bom menino, uma vez que logo se esquecia das orações e praticava uma maldade.

Excerto 7: Omissão de Circunstância e acréscimo de Processo

De manhã, antes do mingau, e de noite, antes da cama (CIR) pedia (VER) a Deus que me perdoasse, assim como eu perdoava (VER) aos meus devedores; mas entre a manhã e a noite fazia uma grande maldade, (...)

Por la mañana, antes del desayuno, y por la noche, antes de acostarme (COM), pedía (VER) a Dios que me perdonase, así como yo perdonaba (VER) a mis deudores; pero entre la mañana y la noche hacía una gran maldad, (...)

O excerto (7) revela a representação de Brás Cubas no TF como Dizente (pedia) que se arrepende de seus pecados cotidianos, uma vez que faz o pedido de perdão a Deus em dois momentos circunstanciais importantes de sua vida de criança: antes do café (antes do mingau) e antes de dormir (de noite) (antes da cama). Contudo, a representação de Brás Cubas criança já apresentava um caráter voltado para a maldade, perversidade, crueldade, pois na sequência, ele não consegue manter seu pedido de perdão e manterse afastado do mal, uma vez que ele, como Ator, volta a fazer (fazia) uma grande maldade. 
No TA, a representação de Brás Cubas como o Dizente (pedia) arrependido de suas maldades diárias, juntamente a duas das três circunstâncias que localizam o processo em um tempo determinado (antes del desayuno e por la noche). Porém, uma das circunstâncias de tempo (antes da cama) é substituída por um processo comportamental (acostarme), que coloca o personagem no papel principal de Comportante junto ao evento. Percebe-se com esta escolha que a equivalência semântica foi mantida pois, antes da cama, foi entendido como o fato do personagem ir deitar-se, não interferindo na representação de Brás Cubas no âmbito da maldade (hacía), mas lhe dá um maior destaque ao colocá-lo como elemento principal da transitividade (Participante), segundo Halliday e Matthiessen (2014).

Vale a pena mencionar que o processo acostarme é tipicamente um processo reflexivo, tipos de verbos que são "muito mais numerosos em espanhol do que em português" e usados para caracterizar comportamentos humanos, tais como "me despierto, me ducho, me peino, me cepillo, me afeito, me visto" (MASIP, 2010, p. 145).

\section{Contexto do Excerto 8:}

O excerto (8) mostra um Brás Cubas que se arrepende de não ter ido ao teatro com Virgília, justamente por pensar que poderia perdêla por esse motivo. É nesse momento que ele resolve ir até a casa de Virgília e fazer as pazes com ela.

\section{Excerto 8: Omissão de Circunstância}

No dia seguinte, não me pude ter ${ }^{8}$ (VER); fui (MAT) cedo à casa de Virgília; achei-a com os olhos vermelhos de chorar.

Al día siguiente no pude contenerme (COM); fui (OMISSÃO) a casa de Virgilia; la encontré con sus párpados rojos de tanto llorar.

${ }^{8}$ A expressão não “me pude ter" é transcrita à sintaxe do português brasileiro atual como "que não lhe falasse" no dicionário de Machado de Assis: língua, estilo, temas, de Castelar de Carvalho (2018, p. 40), daí a classificação como processo verbal. 
O excerto (8) revela a representação de Brás Cubas como um Dizente (pude ter) que não pretende frear a fala que dirigirá à sua amada. Essas experiências ficcionais ocorrem no dia seguinte à ida ao local (à casa de Virgília) e em um horário específico (cedo), desvelando a urgência dessa ação verbal que pretendia realizar.

Nesse excerto, a representação de Brás Cubas no TA sofre uma mudança ideacional em dois aspectos: no processo verbal que passa a ser Comportamental (pude contenerme) e na omissão da Circunstância (cedo), que diminui a urgência do propósito que o personagem tinha em relação à Virgília nessa representação.

\section{Conclusões}

A análise dos dados revela a representação ideacional de Brás Cubas como aquele que age (processos materiais) em seu entorno, pensa e reflete sobre sua vida e sua morte (processos mentais), fala (processos verbais), se comporta (processos comportamentais) e apresenta determinadas características (processos relacionais) no TF. As escolhas linguísticas no TA revelam que, na maior parte do tempo, uma equivalência ideacional na representação de Brás Cubas foi realizada constituindo assim uma mesma figura experiencial deste personagem ficcional e uma mesma representação. Entretanto, algumas escolhas provocaram mudanças ideacionais que alteraram, mesmo que sutilmente, alguns traços da representação ficcional desse personagem (e.g. excertos 1,2 e 4), ao atribuir maior intensidade (excerto 1), ou sofrer uma mudança na ação afetuosa, como no excerto 4, ou mesmo quando ocorre uma alteração na qualidade de ser vivente, como no excerto 2.

Os dados confirmaram as hipóteses da pesquisa. Em primeiro lugar, a de que, embora esperado, houve um predomínio de equivalências ideacionais, uma vez que, do contrário, o texto apresentaria distinções na descrição de seus participantes, processos 
e circunstâncias. Em segundo lugar, constatou-se a identificação de um pequeno número de mudanças ideacionais na representação de Brás Cubas no TA. Em relação às mudanças ideacionais, confirmamos que mudanças na transitividade provocam alterações, mesmo que sutis, na constituição das representações ficcionais do personagem, uma vez que elas ajudam a descrever Brás Cubas e os eventos aos quais ele se vincula. Com isso, percebe-se, como de praxe, a importância dos elementos de transitividade para a descrição de eventos e de personagens, a partir das escolhas linguísticas, como demonstra Montgomery (1993), pois a transitividade também revela as mudanças ideacionais que ocorrem em textos variados, especialmente nos ficcionais, quando ocorre alguma alteração em um ou mais de seus elementos.

Em segundo lugar, confirma-se a hipótese de que a presença de mudanças ideacionais, em alguns casos, não resulta em mudanças na equivalência semântica, validando os resultados encontrados por Rodrigues-Júnior e Garcia de Oliveira (2015, p. 408), ao concluírem que as mudanças ideacionais "nem sempre significa[m] mudança na equivalência semântica" como identificado nos excertos 2, 3 e 7 das análises. Isso ocorre porque a língua é um recurso que possibilita criar diversos significados, mesmo que seja usado de modo distinto.

Conclui-se, portanto, que as mudanças ideacionais podem ser o resultado de escolhas tradutórias no nível da léxico-gramática tomadas a partir de decisões do tradutor com base em uma série de fatores, sistema linguístico, aspectos culturais e na interpretação do TF. Sabe-se, pois, que a equivalência é "influenciada por uma variedade de fatores linguísticos e culturais e que, por isso é sempre relativa“ (BAKER, 1992, p. 6); assim, algumas escolhas podem produzir equivalências, mas outras podem provocar mudanças como se vê nas escolhas do tradutor de Memórias. 


\section{Referências}

ALATORRE, Antonio. Descripción. México: Fondo de Cultura Económica, 1984.

ASSIS, Machado de. Memórias Póstumas de Blás Cubas. Traduzido por Antonio Alatorre. La havana, Cuba: Casa de Las Américas, 1982. Disponível em: https://documentop.com/memorias-postumas-de-blascubas_598dc3491723dd1a9bbc75ff.html. Acesso em: 30 set. 2017.

ASSIS, Machado de. Memórias Póstumas de Brás Cubas. In: ASSIS, Machado de. Obra Completa. Rio de Janeiro: Nova Aguilar, 1994. Disponível em: http://www. dominiopublico.gov.br/download/texto/bvooo215.pdf. Acesso em:26 out. 2017.

BAKER, Mona. In Other Words: A coursebook on translation. Londres, Nova Iorque: Routledge, 1992.

BERBER SARDINHA, Tony. Usando WordSmith Tools na investigação da linguagem. DIRECT Papers, São Paulo, n. 40, 1999. Disponível em: http://www2. lael.pucsp.br/direct/DirectPapers4O.pdf. Acesso em: 15 jun. 2013.

BERBER SARDINHA, Tony. Visão geral da Linguística de Corpus. In: BERBER SARDINHA, Tony. Linguística de corpus. Barueri, SP: Editora Manole, 2004.

DOMínguEZ, C. E. Andanzas Póstumas: Machado de Assis en español. Caracol, São Paulo, n. 1, p. 64-85, 2010. Disponível em: https://www.revistas.usp. br/caracol/article/view/57638/60694. Acesso em: 16 set. 2018.

FARIAS, V. L. C. de. Machado de Assis na imprensa do século XIX: Práticas, leituras e leitores. 2013. 236f. Tese (Doutorado em Letras) - Faculdade de Letras da Universidade Federal de Pernambuco, João Pessoa, 2013. Disponível em: http:// www.cchla.ufpb.br/ppgl/wp-content/uploads/2013/06/images_VirnaLucia.pdf. Acesso em: 16 set. 2018.

FUENTES, Carlos. O milagre de Machado de Assis. Folha de S. Paulo, São Paulo, 1 out. 2000 [com indicação de ter sido publicado originalmente na revista Quimera]. Disponível em: http://www1.folha.uol.com.br/fsp/mais/ fso110200003.htm. Acesso em: 09 abr. 2018. 
FUZER, C.; CABRAL, S. R. S. Introdução à gramática sistêmico-funcional em língua portuguesa. Campinas, SP: Mercado de Letras, 2014.

GHIO, E.; FERNÁNDEZ, M. D. Lingüística Sistémico Funcional: aplicaciones a la lengua española. Santa Fé: Universidad Nacional Del Litoral e Waldhuter Editores, 2008.

HALLIDAY, M. A. K. El Lenguaje como semiótica social: la interpretación social del lenguaje y Del signo. Traduzido por Jorge Ferreiro Santana. México: Fondo de Cultura Econômica, 1982.

HALLIDAY, M. A. K. Towards a Theory of Good Translation. In: STEINER, E.; YALLOP, C. (eds.). Exploring Translation and Multilingual Text Production: beyond content. Berlin, Nova Iorque: Mouton de Gruyter, 2001, p. 13-18.

JAKOBSON, R. On Linguistic Aspects of Translation. In: VENUTI, L. (ed.). The Translation Studies Reader. Londres, Nova Iorque: Routledge, 2000.

LARA, Luis Fernando. Homenaje a Antonio Alatorre. Acta poét, México, v. 32, n. 1, p. 103-115, 2011. Disponíevel em: http://www.scielo.org.mx/scielo. php?script=sci_arttext\&pid=So185-30822011000100005\&lng=es\&nrm=iso. Acesso em: 26 abr. 2019.

LEAL, Luciana, B. Memórias póstumas de Brás Cubas: o narrador melancólico. 2013. 124f. Dissertação (Mestrado em Letras) - Faculdade de Letras da Pontifícia Universidade Católica de Minas Gerais, Belo Horizonte.

MASIP, V. Gramática Española para Brasileños. São Paulo: Parábola, 2010.

MASIP, V.; MATTHIESSEN, C. An introduction to Functional Grammar. Londres, Nova Iorque: Routledge, 2014.

MATTHIESSEN, Christian M. I. M. Talking and Writing about Literature: some observations based on Systemic Functional Linguistics. In: BARBARA, L.; RODRIGUES-JÚNIOR, A. S.; HOY, G. M. V. (org.). Estudos e Pesquisas em Linguística Sistêmico-Funcional. Campinas, SP: Mercado de Letras, 2017, p. 9-51. 
MONTGOMERY, M. Language, Character and Action: a linguistic approach to the analysis of character in a Hemingway short story. In: SINCLAIR, J. M., HOEY, M.; FOX, G. (Ed.). Techniques of Description: spoken and written discourse. London e New York: Routledge, 1993, p. 127-142.

MUNDAY, Jeremy. Evaluation in translation: critical points of translator decision-making. Londres, Nova Iorque: Routledge, 2012.

MUNDAY, Jeremy. Introducing Translation Studies: Theories and pplications. Londres, Nova Iorque: Routledge, 2001.

NIDA, Eugene. Principles of Correspondence. In: VENUTI, L (ed.). The Translation Studies Reader. Londres, Nova Iorque: Routledge, 2000, p. 126-140.

NOVODVORSKI, Ariel; FINATTO, Maria José Bocorny. Linguística de Corpus: abordagem e metodologia em pesquisas linguísticas de base empírica. Letras \& Letras, v. 30, n. 2, 2014, p. 7-16.

PAREDES, A. In memoriam Antonio Alatorre. Períodicos de Poesias, México, n. 1, 2010.

RODRIGUES-JÚNIOR, Adail; GARCIA DE OLIVEIRA, Simone. de. Mudanças Ideacionais das representações linguísticas do heterônimo Álvaro de Campos na obra literária de Fernando Pessoa e em sua tradução para a Língua Inglesa. DELTA, São Paulo, v. 31, n. 2, p.391-410, 2015.

SCHWARRZ, Roberto. Um mestre na periferia do capitalismo: Machado de Assis. São Paulo: Duas Cidades, 1990.

\section{Como citar}

HOY, Giovanna Marcella Verdessi; RODRIGUES- JÚNIOR, Adail Sebastião. Um estudo comparativo das mudanças ideacionais na representação de Brás Cubas no par-linguístico português-espanhol. Revista da Abralin, v. 18, n.1, p. 01-34, 2019.

Recebido em 05/05/2019 e aceito em 05/10/2019 